\title{
Circadian Adrenal Rhythm in Diabetics
}

\author{
D. R. Hadden, J.S. Mackay, B. Sheridan and J.A. Weaver
}

The Sir George E. Clark Metabolic Unit and the Biochemistry Department, Royal Victoria Hospital, Belfast, BT 12, 6 BA, Northern Ireland

Received January 5. 1968

Summary. The circadian rhythm of adrenocortical secretion in 18 diabetic subjects was normal as judged by serial plasma 11-OH-corticosteroid levels. Mild episodes of hypoglycaemia induced a rise in the plasma 11-OH-corticosteroid in 12 diabetic patients on insulin therapy.

Rythme circadien des surrénales chez des diabétiques

Résumé. Le rythme circadien de la sécrétion corticosurrénale de 18 diabétiques était normal, comme on a pu en juger par les taux plasmatiques en série des 11ـOHcorticostéroïdes. Des épisodes d'hypoglycémie modérée ont provoqué une augmentation des 11-OH-corticostéroïdes du plasma chez 12 patients diabétiques sous thérapeutique insulinique. kern

Der Tagesrhythmus der Nebennierenrinde bei Diabeti-

Zusammenfassung. Bei 18 Diabetikern wurde durch Serienbestimmung der Plasma-11-OH-Corticosteroidspiegel ein normaler Tagesrhythmus der NebennierenrindenSekretion gefunden. Leichte Hypoglykämien bewirkten einen Anstieg der 11-OH-Corticosteroidspiegel im Plasma bei 12 insulinbehandelten Diabetikern.

Key-words: Diabetes, Circadian, Adrenal, Rhythm, Hypoglycaemia, 11-OH, Corticosteroid, Insulin Therapy.

patients of comparable age and from the same hospital population were studied as controls under a relatively similar ward routine. In addition, 12 diabetic subjects were studied at the time of the occurrence of a hypoglycaemic insulin reaction. These hypoglycaemic reactions had occurred inadvertently in the course of their diabetic management and were not specifically induced. Blood samples were obtained as soon as possible after the onset of symptoms of hypoglycaemia, before the patient was given oral glucose, and also 30 min later, after such therapy.

\section{Results}

The plasma 11-OH-corticosteroid values for the 18 diabetic subjects and the mean value for the controls is shown in Table 1 . The mean value in the diabetics at $7.00 \mathrm{a} . \mathrm{m}$. was $20.5 \pm 7.3 \mu \mathrm{g} / 100 \mathrm{ml}$, and at 10.00 p.m. was $11.5 \pm 4.5 \mu \mathrm{g} / 100 \mathrm{ml}$. The control subjects showed a similar morning-evening pattern, mean value at 7.00 a.m. $22.3 \pm 5.6 \mu g / 100 \mathrm{ml}$ and at 10.00 p.m. $8.0 \pm 4.8 \mu \mathrm{g} / 100 \mathrm{ml}$. There was no significant difference between the mean plasma 11-OH-corticosteroid levels at these times between control and diabetic subjects, although there was a tendency for the diabetic patients to have slightly higher evening (both $5.30 \mathrm{p.m}$. and $10.00 \mathrm{p.m}$.) plasma $11-\mathrm{OH}$-corticosteroid levels than the controls. The mean blood sugar values in the diabetics are also shown in the lower half of Table 1. When individual plasma 11-OH-corticosteroid and blood sugar values were correlated, there was no significant relationship $(r=0.05)$. In the four patients who showed the least satisfactory "control" of their diabetes in that blood sugars were in the range $200-400 \mathrm{mg} / 100 \mathrm{ml}$, plasma 11-OH-corticosteroid values were slightly higher throughout the day. The mean value for these four patients was $7.9 \mu \mathrm{g} / 100 \mathrm{ml}$ 
Table 1. Circadian rhythm of plasma 11-OH-corticosteroids in patients with diabetes and in controls

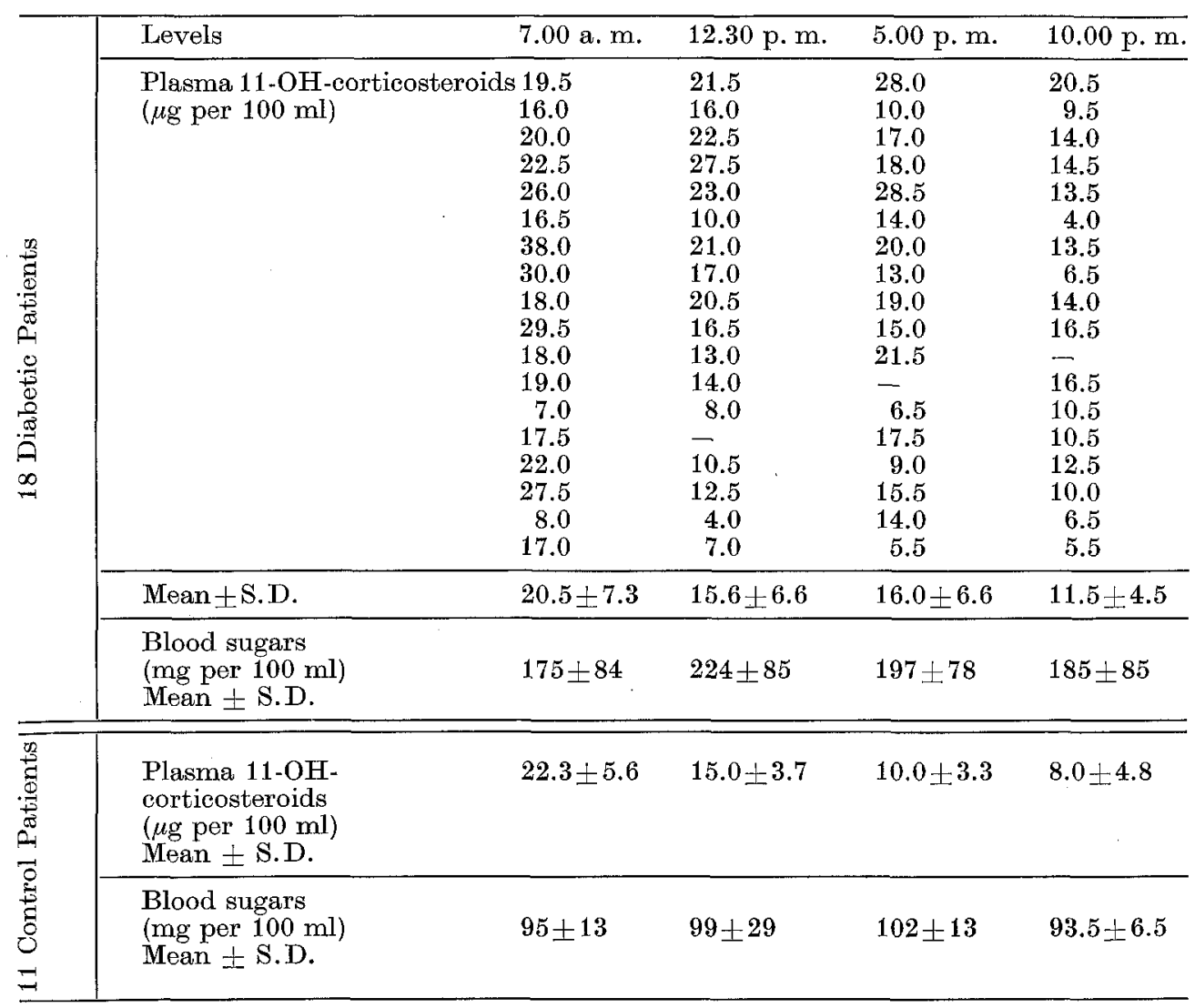

above the mean for the entire group when the four times of estimation were pooled.

Twelve patients were studied at the first symptom of mild hypoglycaemia. The mean blood sugar at this time was $59 \mathrm{mg} / 100 \mathrm{ml}$. The mean plasma $11-\mathrm{OH}$-corticosteroid was $29.0 \mu \mathrm{g} / 100 \mathrm{ml}$ and 30 min later was $30.5 \mu \mathrm{g} / 100 \mathrm{ml}$. When the patients were divided into those experiencing a reaction between early morning and midday and those in whom the hypoglycaemic symptoms occurred in the afternoon or evening, the mean values of plasma 11-0H-corticosteroid were $33.4 \mu \mathrm{g} / 100 \mathrm{ml}$ and $35.7 \mu \mathrm{g} / 100 \mathrm{ml}$ at zero and $30 \mathrm{~min}$ respectively in the morning group, and 25.9 and 26.7 $\mu \mathrm{g} / 100 \mathrm{ml}$ in the afternoon group. To apply statistical tests to these figures the morning and afternoon values have been pooled. The mean morning plasma 11-OHcorticosteroid $(7.00 \mathrm{a} . \mathrm{m}$. and $12.30 \mathrm{p} . \mathrm{m}$.) in the normal subjects was $18.7 \mu \mathrm{g} / 100 \mathrm{ml}$, in the diabetic subjects $18.2 \mu \mathrm{g} / 100 \mathrm{ml}$, and for those experiencing hypoglycaemia during the morning (initial and $30 \mathrm{~min}$ values), $34.5 \mu \mathrm{g} / 100 \mathrm{ml}$. For the afternoon and evening period the respective figures were $9.0 \mu \mathrm{g} / 100 \mathrm{ml}$ (normals) $14.1 \mu \mathrm{g} / 100 \mathrm{ml}$ (diabetics) $26.3 \mu \mathrm{g} / 100 \mathrm{ml}$ (hypoglycaemic patients). Although the groups are small these mean levels in the hypoglycaemic patients are significantly increased ( $t$-tests, $P<0.001$ in each case).

Recently we have studied a patient with prolonged
Table 2. Plasma 11-OH-corticosteroids ( $\mu \mathrm{g}$ per $100 \mathrm{ml}$ ) during hypoglycaemic symptoms

\begin{tabular}{l|ll}
\hline & $\begin{array}{l}\text { Plasma 11-OH-corticosteroids } \\
(\mu \mathrm{g} \text { per 100 ml })\end{array}$ \\
\cline { 2 - 3 } $\begin{array}{l}\text { Time } \\
\text { of }\end{array}$ & $\begin{array}{l}\text { At onset of } \\
\text { hypoglycaemic } \\
\text { symptoms }\end{array}$ & 30 minutes later \\
\hline \multirow{4}{*}{ symptoms } & \\
\hline & 35.0 & 40.0 \\
& 60.0 & 52.0 \\
Mean & 25.0 & 20.0 \\
& 22.5 & 34.0 \\
& 24.5 & 32.5 \\
\cline { 2 - 3 } p. m. & 33.4 & 35.7 \\
& 36.5 & 40.0 \\
& 39.0 & 26.5 \\
& 21.5 & 23.0 \\
Mean & 9.5 & 25.0 \\
\hline Mean & 30.5 & 34.5 \\
overall & 22.0 & 19.5 \\
total & 22.5 & $\mathbf{1 8 . 5}$ \\
\hline & 25.9 & 26.7 \\
\hline
\end{tabular}

and severe hypoglycaemia due to sulphonylurea therapy, where blood sugar levels fell to below $25 \mathrm{mg} /$ 
$100 \mathrm{ml}$ during the evening and night. At $5.30 \mathrm{p.m}$. the 11-OH-corticosteroid level was $25 \mu \mathrm{g} / 100 \mathrm{ml}$; hypoglycaemic symptoms occurred at 6.00 p.m. At 6.30 p.m. the 11-OH-corticosteroid level was $28 \mu \mathrm{g} / 100 \mathrm{ml}$, and at 7.00 p.m. $31 \mu \mathrm{g} / 100 \mathrm{ml}$. At $1.00 \mathrm{a} . \mathrm{m}$. the same night, when hypoglycaemic symptoms recurred, the 11-OH-corticosteroid level in the plasma was still $39 \mu \mathrm{g} / 100 \mathrm{ml}$.

\section{Discussion}

Our finding of a normal circadian rhythm in diabetic subjects is in keeping with earlier studies showing normal adrenal function in diabetes [15]. The study by these workers revealed no evidence of adrenal cortical hyperfunction in patients with uncomplicated diabetes, or in those with diabetic retinopathy and nephropathy. It has been shown that diabetic ketosis elicits an increased adrenocortical response $[11,16]$, but sufficiently severe ketotic states are an uncommon phenomenon in the average diabetic life. Mild or clinically occult hypoglycaemia is not so uncommon and might involve increased adrenal activity consequent to $\mathrm{ACTH}$ release, although other authors have found in normal subjects that severe hypoglycaemia is necessary to activate the adrenal-pituitary system $[2,4,8,17]$.

The plasma 11-OH-corticosteroid results in the 12 hypoglycaemic patients show that this stimulus causes an increased adrenocortical secretion even when the level of blood sugar is only slightly below normal. Several workers $[6,9,13]$ have suggested that it is not the absolute value of the blood sugar but the rate and extent of its fall that is responsible for pituitary adrenal activation. It is worth stressing that the hypoglycaemic symptoms experienced in this group of patients were minimal and consisted of such complaints as weakness, sweating and mild disturbance of cerebration, and no patient became unconscious. Infrequent transient stimulation of adrenocortical activity of this order seems unlikely to have major pathological significance, but it may be worth while to study this phenomenon forther in excessively brittle diabetics in whom a cumulative effect of frequent episodes of rapid onset might have some influence. The levels of plasma 11-OH-corticosteroid achieved during morning and evening reactions are not very different considering that the baseline plasma 11-OH-corticosteroid in the morning is at a higher level. However, the peak level of plasma 11-0H-corticosteroids attained is less and whether this would have any elinical significance with regard to the ability of a patient to recover more rapidly from hypoglycaemia during the morning as opposed to later in the day is not known.

Acknowledgments. We wish to thank Dr. D.A.D. Montgomery, M.B.E., Physician-in-Charge, Sir George E. Clark Metabolic Unit, and Mr. D.W. NeILI, Consultant Biochemist, Belfast Hospitals Group. We are grateful to Miss M. WeLler for secretarial help.

\section{References}

1. Becker, B., G.D. Maengwyn-Davies, D. Rosen, J.S. FrIEDENWALD, and F.C. WINTER: Adrenal cortex and B-vitamins in diabetic retinopathy. Diabetes $\mathbf{3}$, $175-187$ (1954).

2. Bethge, H., D.v.d. Nahmer u. H. ZimmermanN: Der Insulinhypoglykämie-Test als Funktionsprüfung des Hypothalamus-Hypophysen-NebennierenrindenSystems. 1; Bei Normalpersonen. Acta endocr. 54, $668-680$ (1967).

3. Conolly, C.K., and M.R. Willis: Plasma cortisol levels in heart failure. Brit. med. J. 1967 II, 25-26.

4. Greenwood, F.C., I. Landon, and T.C. Stamp: The plasma sugar, free fatty acid, cortisol and growth hormone response to insulin. 1. In control subjects. J. clin. Invest. 45, 429-436 (1966).

5. Irsalo, E., and A. Pekrarinen: Content of free and conjugated 17-hydroxycorticosteroids in plasma of diabetic patients with renal or vascular complications. Ann. Med. intern. Fenn. 54, 121-127 (1965).

6. Jackson, I.M.D., T.H.A. Hassan, C.R.M. Prentice, and M.C.K. BRownING, Insulin-induced hypoglycaemia as a test of pituitary-adrenal function in thyrotoxicosis. J. clin. Endocr. 26, 545-549 (1966).

7. KnaPP, M.S., P.M. Keane, and J.G. Wright: Circadian rhythm of plasma 11-hydroxycorticosteroids in depressive illness, congestive heart failure, and Cushing's syndrome. Brit. med. J. 1967 I, 27-30.

8. LANDoN, J., V. WYNN, and V.H.T. JAMES: The adrenocortical response to insulin-induced hypoglycaemia. J. Endocr. 27, 183-192 (1963).

9. Kratcer, J., and J. Logothetopoulos: Adrenal cortical response to insulin-induced hypoglycaemia in the rat. Acta endocr. 44, 282-290 (1963).

10. KrIEGER, D.T., and H.P. KrIEGER: Circadian variation of the plasma 17 -hydroxycorticosteroids in central nervous system disease. J. clin. Endocr. 26, $929-940(1966)$.

11. Mcarthur, J.W., R.G. Sprague, and H.L. Mason: Urinary excretion of corticosteroids in diabetic acidosis. J. clin. Endocr. 10, 307-312 (1950).

12. Matimalis, D.: A simple fluorimetric method for the estimation of free 11-hydroxycorticoids in human plasma. J. clin. Path. 15, 374-379 (1962).

13. Matsui, N., and J.E. Plager: Rate of blood glucose fall as a determinant factor in insulin-induced adrenocortical stimulation. Endocrinology 79, 737-744 (1966).

14. Mrgeon, C.J., F.H. Tyler, J.P. Mahoney, A. A. FloRentin, H. Castle, E.L. Bliss, and L.T. SAMUels: Diurnal variation of plasma levels and urinary excretion of 17-hydroxycorticosteroids in normal subjects, night workers and blind subjects. J. clin. Endoer. 16, $622-633(1956)$.

15. Rifkin, H., S. Solomon, and S. Lieberman: Role of the adrenal cortex in diabetic retinopathy and nephropathy. Diabetes 7, 9-13 (1958).

16. STowers, J.M.: Hyperfunction of adrenal cortex and insulin resistance in diabetic ketosis. Clin. Sci. 10, $487-496$ (1951).

17. WerK, E.E. Jr., S. Garber, and L.J. Sholiton: Effect of sympathetic blockade on changes in blood ketones and non-esterified fatty acids following hypoglycaemia in man. Metabolism 10, 115-125 (1961).

D. R. HadDen, M. D.

The Sir George E. Clark

Metabolic Unit

Royal Victoria Hospital

Belfast, BT12, 6BA

Northern Ireland 